\title{
US scientists double estimates of ozone depletion rate
} Academy of Sciences has calculated that the worldwide use of halocarbons may be depleting the ozone content of the stratosphere twice as fast as was predicted three years ago. A report published by the academy in 1976, calculating a depletion rate leading to an eventual $7.5 \%$ reduction in ozone, became the basis for a ban in the US, implemented at the end of last year, on all non-essential uses of chlorofluorocarbons, particularly those used as aerosol propellants.

Using improved computer models and better atmospheric and laboratory measurements, the panel on stratospheric chemistry and transport of the Academy's National Research Council now estimates the most probable eventual depletion as $16.5 \%$.

Furthermore, using a model that assumes "an increasing release rate in other industrial countries" - rather than a release rate fixed at the 1977 level, the panel says it is "highly probable" that the eventual steady state reached would
A Committee of the US National

involve a $30 \%$ ozone reduction - and that this could be as high as $56.7 \%$.

The panel points out that many uncertainties still surround such calculations. Since the release of earlier reports indicating the possible danger from fluorocarbon use, however, it points out that there has been a considerable improvement in both computer models and the quality of atmospheric measurements used to check their validity.

These activities have not altered the principal conclusion reached in the previous reports that continued release of halocarbons into the atmosphere will result in a significant decrease in the amount of stratospheric ozone," the report says.

Based on continued emission at the 1977 level the report says its own best estimate of the eventual ozone depletion is $16.5 \%$. It adds that its estimate of uncertainty is such that there is a $95 \%$ probability that the true value of the ozone depletion lies between $5 \%$ and $28 \%$. Ozone reduction to half the eventual level - to $8 \%$ - would occur in about 30 years, the report adds.

\section{Herbicide claimed responsible for birth defects}

A uS chemical trade union claimed last week that the exposure of male workers during production of the herbicide Oryzalin may have resulted in genetic damage to the children that they subsequently conceived.

According to the International Chemical Workers Union, of the four children born to men working in the plant in Rensselaer, New York State, over the period January 1975 to June 1976 during which the herbicide was being produced, three were born with heart deformities - two later dying - and one died from pneumonia two months later. There was also one miscarriage.

Oryzalin is the trade name for the chemical 3,5,-dinitro-N(4), $\mathrm{N}(4)$-dipropylsulfanilamide. It is marketed in the US by Eli Lilly and co, which has denied that there is any evidence connecting the worker's exposure to the birth defects.

The company points out that no birth defects were indicated in laboratory tests carried out with rats and rabbits before the herbicide was approved by the Environmental Protection Agency in 1975. Nor was any evidence discovered after the question of a link to the human birth defects first raised in 1976. However, the assistant administrator of the EPA, Mr Steven Jellinek, said that the Agency was "very concerned" about the union's charges. Although the EPA did not know of any "scientifically established link" between exposure to Oryzalin and these health problems, the union's information indicated that there might well be some hazard, either from the herbicide or from some other substance to which the workers were exposed.

The union has asked the federal government to ban the production and use of Oryzalin, which is used on soybeans for weed control. "We are taking these actions to alert the public to the potentially devastating effects to future generations from exposure to this chemical" said union President Frank D Martino.

Mr Jellinke said that although no problem had shown up in the animal tests, the human experience indicating possible genetic problems with workers exposed to the herbicide "does raise questions". He said that the EPA will set up a team with the Occupational Safety and Health Administration and the National Institute of Occupational Safety and Health to study the effects of the herbicide, and that the report should be ready "within weeks"

Last week the EPA suspended all use of the pesticide DBCP while it decides whether to impose a permanent ban on the chemical, which has been linked both to cancer, and to sterility in male workers involved with its production. The administrator of the EPA, Mr Doug Costle, has ordered all applications of DBCP - most commonly used on fruit trees and soybeans - to be halted except in Hawaiian pineapple groves.

David Dickson
US sifts ex-Nazi scientists for possible war criminals

THE US Department of Justice, stepping up its search for Nazi war criminals who may now be resident in the United States, is investigating whether any were included in the 500 scientists and engineers who were brought over from Germany at the end of the second World War to work on weapons research.

No details have been given of the names of individuals under investigation. However, Justice Department officials confirmed last week that some of the scientists and engineers involved in what was known as "operation paperclip" are among the department's list of 200 to 250 suspected war criminals.

Under the programme, which operated from 1945 to 1955 , over 3000 German and Austrian scientits who had worked for the Nazis were checked by US authorities to discover whether their skills could be of value to the US military efforts - and thus might also be of value to the Soviet Union.

Over 500 were subsequently brought to the US under a programme approved by President Truman, despite strong opposition from scientists such as Albert Einstein.

Since it was felt that it was in the interests of national security to bring them to the US, the scientists and engineers were admitted without having to pass the usual immigration and visa checks, even though some were known to have been members of the Storm Troopers, and the League of National Socialist German Physicians.

Perhaps the best known of those admitted were the members of the team which worked on guided missiles under Dr Werner von Braun, and were largely responsible for launching the first US satellite in 1958. However, the US also brought over experts from a variety of other disciplines, such as three scientists who had worked on the German chemical weapons programme, who went to work for the Army's Chemical Warfare Division.

Mr Martin Mendelsohn, deputy director of the Justice Department's newly-created office to investigate Nazi war criminals, said last week that membership of a Nazi organisation was not necessarily sufficient to invoke charges, which required evidence of war crimes. He confirmed that his of fice is now examining the files of all those brought to the US under operation paperclip to see if any cases should be pursued further.

A typical case demanding attention, according to a staff member of the Senate committee which is pushing the Administration for action on war criminals, is that of a former concentration camp medical officer who came to the US to work on a variety of aviation medicine projects. 